\title{
PERFORMANCE OF PRILLED UREA AND UREA SUPER GRANULES ON THE GROWTH AND YIELD OF WHEAT
}

\author{
L. Nahar ${ }^{1}$, M. H. Ali ${ }^{2}$, S. M. Masum ${ }^{2}$, M. M. Mahbub ${ }^{3}$ and S. R. Haque ${ }^{4}$ \\ ${ }^{1}$ Scientific Officer, Agronomy Division, Bangladesh Rice Research Institute, Gazipur-1701 \\ ${ }^{2}$ Department of Agronomy, Sher-e-Bangla Agricultural University, Dhaka-1207 \\ ${ }^{3}$ Scientific Officer, Agronomy Division, Bangladesh Rice Research Institute, Gazipur-1701 \\ ${ }^{4}$ Scientific Officer, Bangladesh Agricultural Research Institute, Gazipur-1701
}

Key words: Prilled Urea, Urea Super Granules, Growth and Yield, Wheat

\begin{abstract}
An experiment was conducted at the Agronomy Field of Sher-e-Bangla Agricultural University, Dhaka-1207 during the period from November 2011 to March 2012 to evaluate the performance of prilled urea and urea super granules (USG) on the growth and yield of wheat varieties. The experiment comprised of four wheat varieties viz., BARI Gom 21, BARI Gom 24, BARI Gom 25 and BARI Gom 26, and five nitrogen (N) levels viz., control (no Nitrogen), $84 \mathrm{~kg} \mathrm{ha}^{-1} \mathrm{~N}$ from USG, and 30, 50 and $70 \mathrm{~kg} \mathrm{~N}$ $\mathrm{ha}^{-1}$ from prilled urea i.e., 67, 112 and $155 \mathrm{~kg}$ urea ha-1. The experiment was laid out in a split-plot design with three replications where wheat varieties were placed in the main plot and nitrogenous fertilizers in sub-plots. Experimental results indicated that different varieties had the significant effect on plant height, number of tillers and dry weight plant ${ }^{-1}$, and number of grains spike $e^{-1}$, grain and straw yield, and harvest index. The variety BARI Gom 24 produced the highest grain yield $\left(2.49 \mathrm{t} \mathrm{ha}^{-1}\right)$ that mainly attributed by the maximum number of spikes plant ${ }^{-1}$, number of grains spike $e^{-1}$ and 1000 -grain weight. Among the different nitrogenous fertilizers $84 \mathrm{~kg} \mathrm{~N} \mathrm{ha}^{-1}$ from USG $(1.8 \mathrm{~g})$ gave the highest grain yield $\left(2.69 \mathrm{t} \mathrm{ha}^{-1}\right)$ due to the maximum number of spikes plant ${ }^{-1}$, maximum number of grains spike $e^{-1}$ and 1000 -grain weight. The variety BARI Gom 24 produced the highest grain yield $\left(2.80 \mathrm{t} \mathrm{ha}^{-1}\right)$ with $80 \mathrm{~kg} \mathrm{~N} \mathrm{ha}{ }^{-1}$ from USG application.
\end{abstract}

\section{Introduction}

Wheat (Triticum aestivum L.) is ranked first both in acreage and production among cereal crops in the world but second most important stable food crop in Bangladesh.. Scarcity of food may become a chronic problem in future. To mitigate the food shortages, measures should be taken to increase the total food production. So, the yield of wheat will be needed to increase to boost up its production Wheat cultivation is easier and requires less time and irrigation than other alternative crops like boro rice, legumes and potato; additionally it needs low cultivation cost. The crop is grown under different environmental conditions ranging from humid to arid, sub tropical to temperate zone (Saari, 1998). The area under wheat cultivation during 2007-2008 was about 5.59 lakh hectares producing 9.76 lakh tons of wheat with an average yield of 1.75 ton per hectare (BBS, 2008). However, wheat production has generally stagnated due to high cost of production and low level of technology (Onsongo, 2003). Proper using techniques and doses of fertilizers are mostly important for better growth for any crops. Among the fertilizers, $\mathrm{N}$ plays a vital role in producing higher grain yield. . Rate of $\mathrm{N}$ application has a great influence on growth, development and yield of wheat. Wheat yield increases with the increase of nitrogenous fertilizer (Singh et al., 1986). Grain yield of wheat increases with increasing $\mathrm{N}$ level up to $120 \mathrm{~kg} \mathrm{ha}^{-1}$ (Malik, 1981 and Sarker et al., 1997). Prilled urea is a fast releasing 
Nahal et al.

nitrogenous fertilizer which is usually broadcast in splits, that causes considerable loss as ammonia volatilization, immobilization, denitrification and surface run off etc. On the other hand, deep placement of slow releasing nitrogenous fertilizer such as USG reduces loss as well as increases its use efficiency in dry land rabi crops (Islam et.al., 2011). Proper application of USG can increase yields and fertilizer-N utilization of wheat and simultaneously decrease $\mathrm{N}$ losses compared to equivalent use of prill (Khalil et al., 2011). Therefore, the present experiment was conducted tofind out the effect of prilled urea and USG on the growth and yield of wheat as well asfind out the optimum dose of nitrogenous fertilizer for the variety

\section{Materials and Methods}

The experiment was carried out at the Agronomy field, Sher-e-Bangla Agricultural University, Dhaka-1207 during the period of 14 November 2011 to 15 March 2012. The soil of the experimental site was clay loam belonging to the AEZ 28 (Madhupur Tract). The selected plot was medium high land. and above flood level Soil samples from 0-15 cm depth were collected from experimental plot. Details of the soil analysis have been shown in Table 1.

Table 1. Chemical properties of soil in the study area

\begin{tabular}{ll}
\hline Soil characteristics & Analytical value \\
\hline $\mathrm{pH}$ & $5.47-5.63$ \\
Organic matter (\%) & 2.01 \\
Total N (\%) & 0.20 \\
Available P & $22 \mathrm{ppm}$ \\
Exchangeable K & $0.42 \mathrm{meq} / 100 \mathrm{~g}$ soil \\
\hline
\end{tabular}

The experiment comprised of wheat varieties and $\mathrm{N}$ levels, and was laid out in a split-plot design with three replications. Four wheat varieties viz., BARI Gom $21\left(\mathrm{~V}_{1}\right)$, BARI Gom 24 $\left(\mathrm{V}_{2}\right)$, BARI Gom $25\left(\mathrm{~V}_{3}\right)$ and BARI Gom $26\left(\mathrm{~V}_{4}\right)$ were assigned to the main plots, while five N levels viz., control (no nitrogenous fertilizer) $\left(\mathrm{N}_{0}\right), 84 \mathrm{~kg} \mathrm{~N} \mathrm{ha}{ }^{-1}$ from USG $\left(\mathrm{N}_{1}\right), 30 \mathrm{~kg} \mathrm{~N} \mathrm{Na}^{-1}$ from prilled urea $\left(\mathrm{N}_{2}\right), 50 \mathrm{~kg} \mathrm{~N}^{-1}$ from prilled urea $\left(\mathrm{N}_{3}\right)$ and $70 \mathrm{~kg} \mathrm{~N}$ ha ${ }^{-1}$ from prilled urea $\left(\mathrm{N}_{4}\right)$ were assigned to the sub-plots. USG (two pieces $0.9 \mathrm{~g}$ each) was placed i.e., 50 and 20 $\mathrm{cm}$ distance in rows and plants, respectively. The unit plot size was $3 \mathrm{~m} \times 3 \mathrm{~m}$. The land was prepared with power tiller on 12 November 2011. A blanket dose of manures and fertilizers were applied @ 3,000-30-10-24-5 kg ha-1 cowdung-Nitrogen-TSP-MoP-Gypsum (FRG, 2005). The whole amount of TSP, MoP, gypsum and two-third of prilled urea (except for control treatment) were incorporated in each plot at the time of final land preparation. Rest one-third of prilled urea was applied at crown root initiation (CRI) stage i.e., 21 days after sowing (DAS). USG was applied only once at a time into the field at CRI stage after irrigation. At a good tilth condition, furrows were made $25 \mathrm{~cm}$ apart with hand rakes for sowing. Before sowing, seeds were treated with Provax $200 @ 2.5 \mathrm{~g}$ powder for $1 \mathrm{~kg}$ seed. Seeds were sown continuously in lines on 14 November $2011 @ 125 \mathrm{~kg} \mathrm{ha}^{-1}$. After sowing, the seeds were covered with soil and lightly pressed by hand. Intercultural operations were done to ensure normal growth of the crop. Three irrigations were applied at 21, 45 and 62 DAS i.e., at CRI stage, heading stage and grain filling stage, respectively. Weeding was done twice at 20 and 40 DAS. During the irrigation care was taken so that water could not flow from one plot to another or overflow the boundary of the plot. The varieties BARI Gom 21, 24, 25 and 26 were harvested on 04 March, 28 February, 28 February and 01 March 2012, respectively at physiological maturity. 
Performance of Prilled Urea and USG on the Growth and Yield of Wheat

Prior to harvest, five hills from each plot were selected randomly (excluding border hills) to collect the data on plant characters, yield attributes and yield. Biological yield was calculated from the following formula.

Biological yield $\left(\mathrm{t} \mathrm{ha}^{-1}\right)=$ Grain yield $\left(\mathrm{t} \mathrm{ha}^{-1}\right)+$ Straw yield $\left(\mathrm{t} \mathrm{ha}{ }^{-1}\right)$.

Harvest index was calculated as the ratio of economic yield (grain yield) to biological yield and expressed in terms of percentage. It was calculated by using the following formula (Donald, 1963).

Harvest index $(\%)=\frac{\text { Grain yield }}{\text { Biological yield }} \times 100$

The collected data on each plot were statistically analyzed and mean difference among the treatments were tested with the least significant difference (LSD) at $5 \%$ level of significance.

\section{Results and Discussion}

\section{Effect of variety}

The effect of variety on plant height was significant at all sampling dates such as $15,30,45$, 60, 75, 90 DAS and at harvest (Fig. 1). The variety BARI Gom 21 produced the tallest plants (94.9, 97.9 and $99.4 \mathrm{~cm}$ at 75, 90 DAS and at harvest, respectively) which was superior to all other varieties. But at 15, 30, 45 and 60 DAS the variety BARI Gom 25 produced the maximum plant height $(33.1,36.5,56.9$ and $88.2 \mathrm{~cm}$, respectively) which was statistically similar to the variety BARI Gom 26 at 30 DAS. On the other hand, the variety BARI Gom 21 was shorter than other varieties from 15 DAS to at 60 but it was observed that at 75, 90 DAS and at harvest the variety BARI Gom 24 produced the shorter plants $(90.3,91.9$ and $91.9 \mathrm{~cm}$, respectively). The results obtained from the present study were conformity with the findings of Tariq (2010), Rahman et al. (2009). The result revealed that the effect of variety on number of tillers plant ${ }^{-1}$ was significant at all sampling dates (Fig. 2). The variety BARI Gom 24 produced the maximum number of tillers plant ${ }^{-1}(2.9,3.5,3.5,4.3,4.9,4.9$ and 4.6 at 15, 30, 45, 60, 75, 90 DAS and at harvest, respectively) which was statistically similar with the variety BARI Gom 21 at 30, 45, 75 DAS and at harvest. Results also showed that the variety BARI Ghom 26 was statistically similar to the variety BARI Gom 24 at 15, 30 and 60 DAS. On the other hand, the variety BARI Gom 21 produced the minimum number of tillers plant ${ }^{-1}$ at 15 DAS (2.53) but at 30, 45, 60, 75, 90 DAS and at harvest the variety BARI Gom 25 produced the minimum $(2.91,3.07,4.07,4.78,4.35$ and 4.36 , respectively) which was identical to the variety BARI Gom 26 at 45 DAS and at harvest. The results obtained from the present study were similar to the findings of Nadim et al. (2012), Hussain et al. (2010) and Tariq (2010). Significant variation was observed in dry weight plant ${ }^{-1}$ at all sampling dates (Fig. 3). Results indicated that at 30 DAS, variety had no significant effect but at 60,90 DAS and at harvest and the variety BARI Gom 24 produced significantly higher dry weight plant ${ }^{-1}(6.34,15.48$ and $18.19 \mathrm{~g}$, respectively). Results also showed that the variety BARI Gom 25 produced the lowest dry weight plant ${ }^{-1}$ at 30, 60, 90 DAS and at harvest $(5.8,13.8$ and $16.9 \mathrm{~g}$, respectively) which was statistically similar to the variety BARI Gom 21 and BARI Gom 26 at the time of harvest. 
Nahal et al.

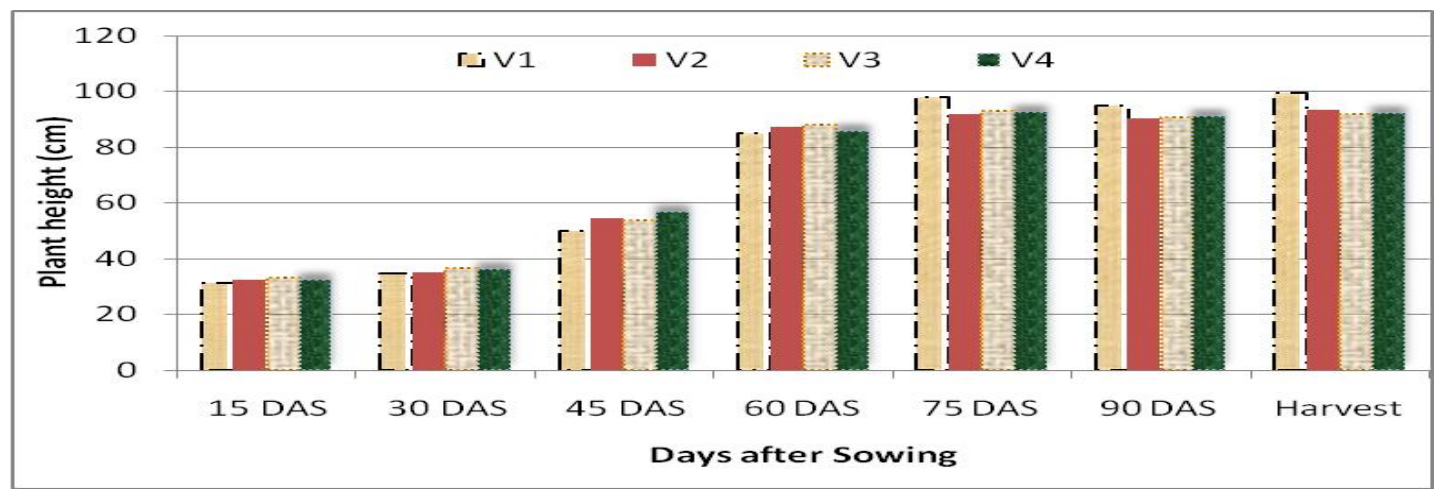

$V_{1}=$ BARI Gom 21, $V_{2}=$ BARI Gom 24, $V_{3}=$ BARI Gom 25 and $V_{4}=$ BARI Gom 26

Fig. 1. Plant height as influenced by four improved varieties of wheat at different growth stages during November' 2011 to March' 2012. $\operatorname{LSD}(0.05)=0.72,0.58,0.78,0.80,0.68$, 0.80 and 0.82 at $15,30,45,60,75$ DAS and at harvest, respectively.

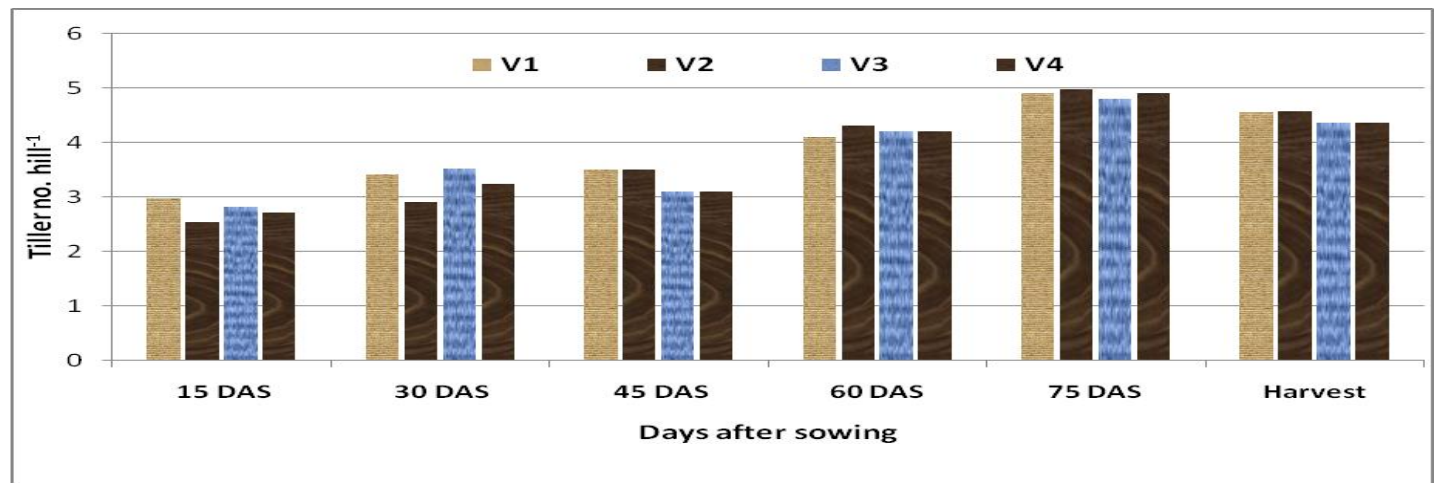

$\mathrm{V}_{1}=$ BARI Gom 21, $\mathrm{V}_{2}=$ BARI Gom 24, $\mathrm{V}_{3}=$ BARI Gom 25 and $\mathrm{V}_{4}=$ BARI Gom 26

Fig. 2. Tiller number per hill as influenced by four improved varieties of wheat at different growth stages during November' 2011 to March' 2012. LSD( 0.05$)=0.35,0.37,0.31$, $0.13,0.12,0.08$ and 0.11 at 15, 30, 45, 60, 75, 90 DAS and at harvest, respectively.

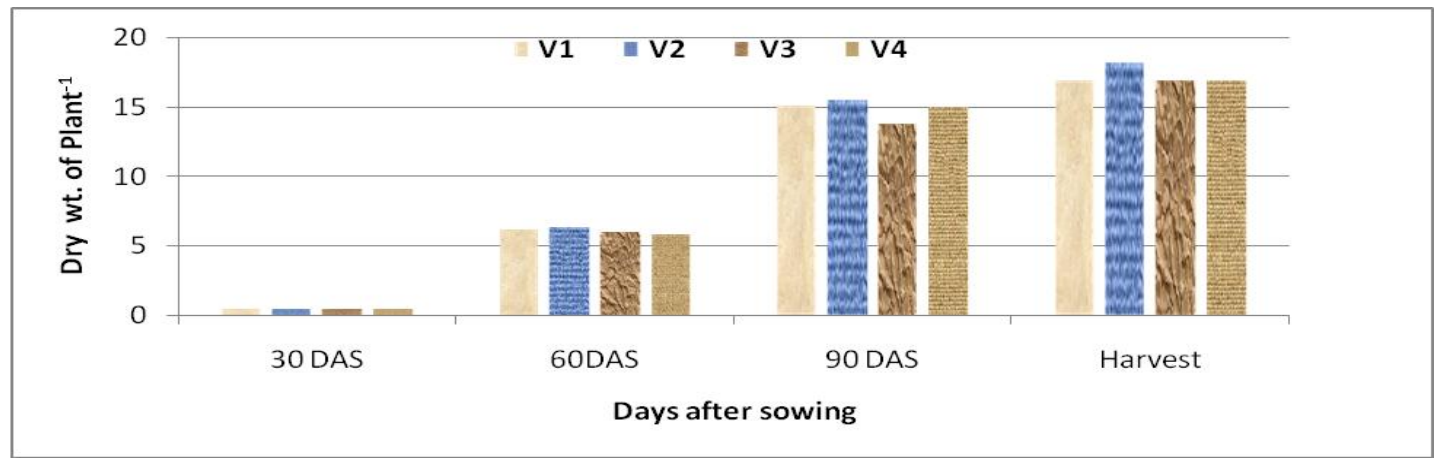

$\mathrm{V}_{1}=$ BARI Gom 21, $\mathrm{V}_{2}=$ BARI Gom 24, $\mathrm{V}_{3}=$ BARI Gom 25 and $\mathrm{V}_{4}=$ BARI Gom 26

Fig. 3. Dry weight plant ${ }^{-1}$ as influenced by four improved wheat varieties during to November' 2011 to March' 2012. LSD( $(0.05)=\mathrm{NS}, 0.24,0.32$ and 0.28 at 30, 60, 90 DAS and at harvest, respectively 
Number of spikelets spike-1 was significantly influenced by different varieties (Table 2). The highest number of spikelets spike ${ }^{-1}$ was found in variety BARI Gom 24 and the lowest in BARI Gom 25. Similar results were found by Nadim et al. (2012), Hussain et al. (2001) and Rahman (2009). Number of grains spike ${ }^{-1}$ was significantly influenced by different varieties where highest number of grains spike ${ }^{-1}$ (37.10) was found in BARI Ghom 24and the lowest number of grains spike $e^{-1}$ (33.50) in BARI Gom 25 (Table 2). The results were similar with the findings of Rahman et al. (2009), and Sikder et al. (2001). Weight of 1000 grains was significantly influenced by different varieties where highest 1000 -grain weight $(58.66 \mathrm{~g})$ was found in BARI Gom 25 and the lowest weight $(52.68 \mathrm{~g})$ in BARI Gom 21. Grain yield was significantly influenced by different varieties and the highest grain yield $\left(2.49 \mathrm{t} \mathrm{ha}^{-1}\right)$ was found in BARI Gom 24) which was statistically similar to BARI Ghom 26 . On the other hand the lowest grain yield (2.28 $\mathrm{t} \mathrm{ha}^{-1}$ ) was found in BARI Ghom 25 which was statistically similar to BARI Gom 21. Straw yield was significantly influenced by different varieties and maximum straw yield (3.57 t ha $^{-1}$ ) was found in BARI Gom 21 which was statistically similar to BARI Gom 24 and BARI Ghom 25. On the other hand the lowest straw yield $\left(3.53 \mathrm{t} \mathrm{ha}^{-1}\right)$ was found in BARI Ghom 26). Similar result was found by Hussain et al. (2010). Results showed that the maximum harvest index (41.08\%) was found in BARI Gom 24 which was statistically similar to BARI Ghom 26 and the lowest (39.00\%) in BARI Gom 25 but similar to BARI Gom 21.

Table 2. Yield and yield contributing parameters and harvest index of wheat as influenced by variety

\begin{tabular}{l|c|c|c|c|c|c}
\hline Variety & $\begin{array}{c}\text { Number } \\
\text { of } \\
\text { spikelets } \\
\text { spike }\end{array}$ & $\begin{array}{c}\text { Number of } \\
\text { grains spike }^{-1}\end{array}$ & $\begin{array}{c}1000- \\
\text { grain } \\
\text { weight } \\
(\mathrm{g})\end{array}$ & $\begin{array}{c}\text { Grain } \\
\text { yield } \\
\left(\mathrm{t} \mathrm{ha}^{-1}\right)\end{array}$ & $\begin{array}{c}\text { Straw yield } \\
\text { (t ha-1) }\end{array}$ & $\begin{array}{c}\text { Harvest } \\
\text { index (\%) }\end{array}$ \\
\hline $\mathrm{V}_{1}$ & 16.66 & 36.15 & 52.68 & 2.32 & 3.57 & 39.29 \\
$\mathrm{~V}_{2}$ & 17.23 & 37.10 & 58.11 & 2.49 & 3.55 & 41.08 \\
$\mathrm{~V}_{3}$ & 15.72 & 33.50 & 58.66 & 2.28 & 3.55 & 39.00 \\
$\mathrm{~V}_{4}$ & 16.61 & 36.30 & 56.31 & 2.43 & 3.53 & 40.69 \\
$\mathrm{LSD}(0.05)$ & 0.29 & 0.64 & 0.321 & 0.096 & 0.033 & 1.213 \\
$\mathrm{CV}(\%)$ & 6.34 & 4.60 & 6.78 & 10.4 & 9.56 & 9.20 \\
\hline
\end{tabular}

$V_{1}=$ BARI Gom 21, $V_{2}=$ BARI Gom 24, V $3=$ BARI Gom 25 and $V_{4}=$ BARI Gom 26

\section{Effect of $\mathrm{N}$ level and source of $\mathrm{N}$}

The plant height differed significantly among the different nitrogenous fertilizer at all sampling dates (Fig. 4). The tallest plant was found in $100 \mathrm{~kg} \mathrm{~N}^{-1}$ from prilled urea (at all sampling dates $(32.9,36.3,54.3,88.0,92.5,95.6$ and $94.9 \mathrm{~cm}$ at 15, 30, 45, 60, 75, 90 DAS and at harvest, respectively). On the other hand, the shorter plant was found in control $\left(\mathrm{N}_{0}\right)$ treatment throughout the growing season but at 15 DAS, the shortest plant was found in $120 \mathrm{~kg} \mathrm{~N} \mathrm{ha}^{-1}$ from prilled urea $\left(\mathrm{N}_{4}\right)$. The result obtained from the present study was conformity with the findings of Rahman (2005) and Akter (2005). Significant variation was observed on number of tillers plant ${ }^{-1}$ in case of different forms of $\mathrm{N}$ application in the field (Fig. 5). It was found that the maximum number of tillers plant ${ }^{-1}$ was found in $80 \mathrm{~kg} \mathrm{~N} \mathrm{ha}^{-1}$ from USG $\left(\mathrm{N}_{1}\right)$ at all sampling dates which was statistically similar to $\mathrm{N}_{4}$ at 60,75 DAS and at harvest. On the other hand, the lowest number of tillers plant ${ }^{-1}(2.41,2.89,3.00,3.94,4.55,3.76$ and 3.41 at 15,30 , $45,60,75,90$ DAS and at harvest, respectively) was found in control which was statistically similar to $80 \mathrm{~kg} \mathrm{~N}$ ha $^{-1}$ from prilled urea at 75 DAS and to $\mathrm{N}_{3}$ at 60 DAS. Significant variation was observed on dry weight plant $^{-1}$ in case of different forms of nitrogenous fertilizer 
Nahal et al.

application in the field (Fig. 6). It was found that the highest dry weight plant ${ }^{-1}$ was found in $\mathrm{N}_{1}$ treatment at all sampling dates $(0.62,7.40,17.64$ and $20.40 \mathrm{~g}$ at 30,60, 90 DAS and at harvest, respectively). On the other hand, the minimum dry weight plant ${ }^{-1}(0.21,4.11,9.61$ and $10.80 \mathrm{~g}$ at 30,60, $90 \mathrm{DAS}$ and at harvest, respectively) was found in control.

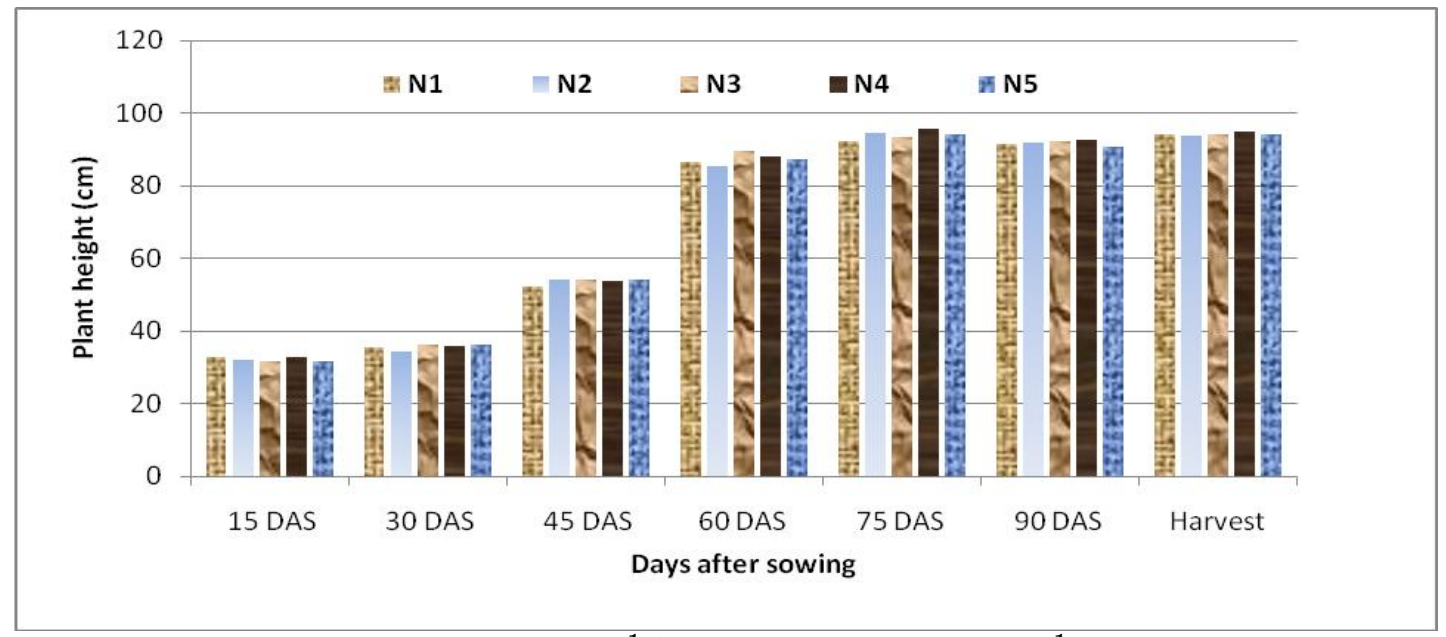

$\mathrm{N}_{0}=$ control (no nitrogen), $\mathrm{N}_{1}=84 \mathrm{~kg} \mathrm{~N} \mathrm{ha}^{-1}$ from USG, $\mathrm{N}_{2}=30 \mathrm{~kg} \mathrm{~N} \mathrm{ha}^{-1}$ from prilled urea, $\mathrm{N}_{3}=50$ $\mathrm{kg} \mathrm{N} \mathrm{ha}^{-1}$ from prilled urea and $\mathrm{N}_{4}=70 \mathrm{~kg} \mathrm{~N}^{-1}$ from prilled urea

Fig. 4. Plant height as influenced by urea super granules (USG) and prilled urea on growth of improved wheat varieties from November' 2011 to March' 2012. $\mathrm{LSD}_{(0.05)}=0.66$, $0.54,0.73,0.86,0.71,0.83$ and 0.88 at $15,30,45,60,75,90$ DAS and at harvest, respectively

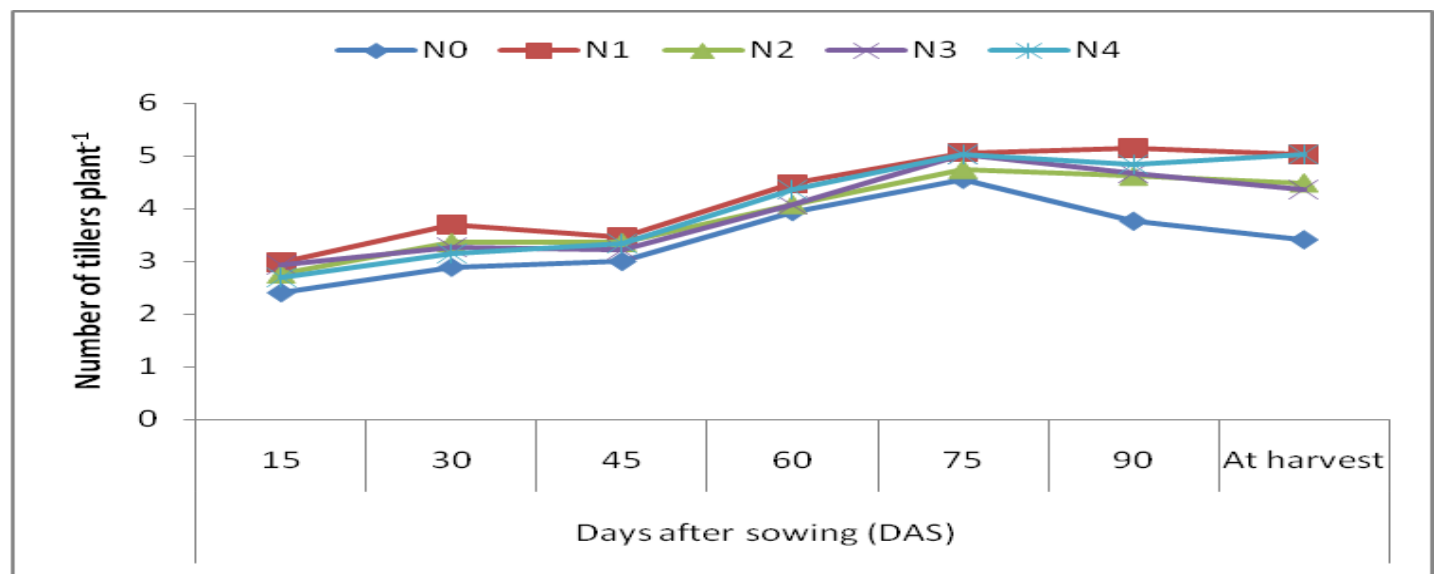

$\mathrm{N}_{0}=$ control (no nitrogen), $\mathrm{N}_{1}=84 \mathrm{~kg} \mathrm{~N}^{-1}$ from USG, $\mathrm{N}_{2}=30 \mathrm{~kg} \mathrm{~N}^{-1}$ from prilled urea, $\mathrm{N}_{3}=50 \mathrm{~kg} \mathrm{~N}$ ha ${ }^{-1}$ from prilled urea and $\mathrm{N}_{4}=70 \mathrm{~kg} \mathrm{~N}$ ha $^{-1}$ from prilled urea

Fig. 5: Effect on number of tillers plant ${ }^{-1}$ as influenced by urea super granules (USG) and prilled urea on growth of improved wheat varieties from November' 2011 to March' 2012. $\operatorname{LSD}(0.05)=0.29,0.32,0.34,0.13,0.23,0.091$ and 0.24 at $15,30,45,60,75,90$ DAS and at harvest, respectively 
Performance of Prilled Urea and USG on the Growth and Yield of Wheat

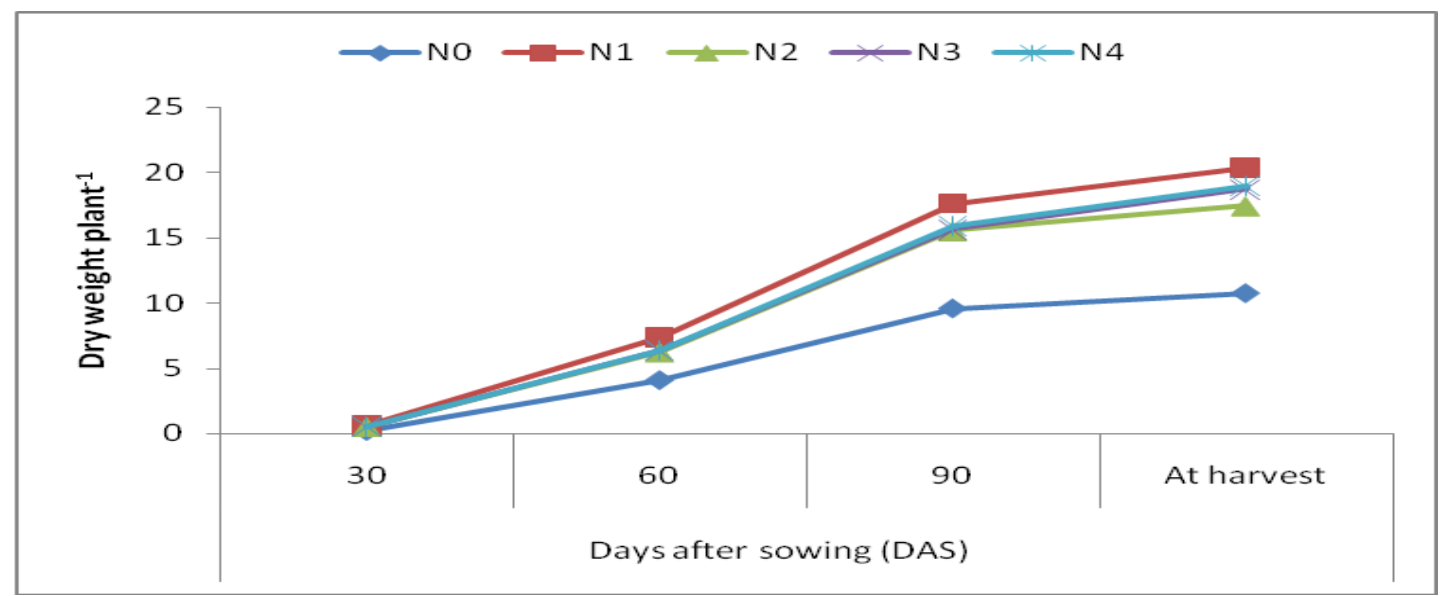

$\mathrm{N}_{0}=$ control (no nitrogen), $\mathrm{N}_{1}=84 \mathrm{~kg} \mathrm{~N} \mathrm{ha}^{-1}$ from USG, $\mathrm{N}_{2}=30 \mathrm{~kg} \mathrm{~N} \mathrm{ha}^{-1}$ from prilled urea, $\mathrm{N}_{3}=50$ $\mathrm{kg} \mathrm{N} \mathrm{ha}^{-1}$ from prilled urea and $\mathrm{N}_{4}=70 \mathrm{~kg} \mathrm{~N} \mathrm{ha}^{-1}$ from prilled urea

Fig. 6. Dry weight plant ${ }^{-1}$ as influenced by urea super granules (USG) and prilled urea on growth of improved wheat varieties from November' 2011 to March' 2012. $\operatorname{LSD}(0.05)=0.069,0.27,0.35$, and 0.31 at $30,60,90 \mathrm{DAS}$ and at harvest, respectively

Significant variation was observed in number of spikelets spike $e^{-1}$ in case of different forms of $\mathrm{N}$ application (Table 3). The highest number of total spikelets spike $e^{-1}(20.63,1.05$ and 21.76, respectively) were achieved from USG application and the lowest number of total spikelets spike $e^{-1}\left(9.43,4.70\right.$ and 13.89 , respectively) was found in $\mathrm{N}_{0}$ (control). Similar results were found by Hossain et al. (2005) and Mozumder (2001). Significant variation was observed on number of grains spike ${ }^{-1}$ and the highest number of grains spike $e^{-1}$ (44.05) was achieved from USG application. On the other hand, the lowest number of grains spike $e^{-1}(24.86)$ was found in $\mathrm{N}_{0}$ (control). Significant variation was observed on 1000-grain weight in case of different forms of $\mathrm{N}$ application where the highest 1000-grain weight $(64.66 \mathrm{~g})$ was achieved from USG application and the lowest 1000 -grain weight $\left(45.26 \mathrm{~g}\right.$ ) was found in $\mathrm{N}_{0}$ (control). Significant variation was observed on grain yield in case of different forms of $\mathrm{N}$ application where highest grain yield $\left(2.69 \mathrm{t} \mathrm{ha}^{-1}\right)$ was achieved from USG application with $80 / 84 \mathrm{~kg} \mathrm{ha}^{-1}$. On the other hand, the lowest grain yield $\left(1.97 \mathrm{t} \mathrm{ha}^{-1}\right)$ was found in $\mathrm{N}_{0}$ (control). The results obtained from the present study was conformity with the findings of Rahman (2005), Akter (2005) and Yadav et al. (2005). The maximum straw yield (3.59 $\left.\mathrm{t} \mathrm{ha}^{-1}\right)$ was achieved from USG which was statistically similar to $80-120 \mathrm{~kg} \mathrm{~N}^{-1}$ from prilled urea while the lowest straw yield (3.43 tha1) was found in $\mathrm{N}_{0}$ (control). The highest harvest index (43.96\%) was achieved from USG application and the lowest harvest index (35.69\%) was found in $\mathrm{N}_{0}$ (control).

\section{Interaction effect of variety and nitrogen}

The plant height differed significantly due to the interaction effect of variety and different nitrogenous fertilizer at all sampling dates (Table 4). Results showed that the maximum plant height was obtained from $\mathrm{V}_{3} \mathrm{~N}_{3}$ at 15, 30, 45 and 60 DAS (34.5, 40.7, 59.3 and 90.1, respectively) which was statistically similar to $\mathrm{V}_{2} \mathrm{~N}_{3}$ and $\mathrm{V}_{3} \mathrm{~N}_{0}$ at 15 and 60 DAS and $\mathrm{V}_{3} \mathrm{~N}_{4}$ at 60 DAS. But at 75, 90 DAS and at harvest the tallest plant was obtained from $\mathrm{V}_{1} \mathrm{~N}_{3}(98.2$, 100.4 and $100.7 \mathrm{~cm}$, respectively). On the other hand the shortest plant $(30.0 \mathrm{~cm})$ was obtained from $\mathrm{V}_{2} \mathrm{~N}_{4}$ combination at 15 DAS, but at 30, 45 and 60 DAS, the shortest plant 
Nahal et al.

$\operatorname{inV}_{1} \mathrm{~N}_{0}$ combination and at 75,90 DAS and at harvest, the shortest plant was obtained from $\mathrm{V}_{2} \mathrm{~N}_{0}$ combination.

Table 3. Yield and yield contributing parameters and harvest index of wheat varieties as influenced by prilled urea and USG

\begin{tabular}{l|c|c|c|c|c|c}
\hline Treatments & $\begin{array}{c}\text { Number of } \\
\text { spikelets } \\
\text { spike }\end{array}$ & $\begin{array}{c}\text { Number } \\
\text { of } \\
\text { grains } \\
\text { spike }\end{array}$ & $\begin{array}{c}1000- \\
\text { grain } \\
\text { weight } \\
\text { (g) }\end{array}$ & $\begin{array}{c}\text { Grain } \\
\text { yield } \\
\left(\mathrm{t} \mathrm{ha}^{-1}\right)\end{array}$ & $\begin{array}{c}\text { Straw yield } \\
\left(\mathrm{t} \mathrm{ha}^{-1}\right)\end{array}$ & $\begin{array}{c}\text { Harvest } \\
\text { index (\%) }\end{array}$ \\
\hline \multicolumn{6}{c}{ N level and source of N } \\
$\mathrm{N}_{0}$ & 9.43 & 24.9 & 45.3 & 1.9 & 3.43 & 35.7 \\
$\mathrm{~N}_{1}$ & 20.6 & 44.0 & 64.7 & 2.7 & 3.60 & 43.9 \\
$\mathrm{~N}_{2}$ & 17.8 & 36.5 & 56.8 & 2.4 & 3.60 & 40.2 \\
$\mathrm{~N}_{3}$ & 17.5 & 36.5 & 57.9 & 2.3 & 3.60 & 39.2 \\
$\mathrm{~N}_{4}$ & 17.4 & 36.7 & 57.6 & 2.5 & 3.60 & 41.0 \\
LSD (0.05) & 0.31 & 1.23 & 0.32 & 0.11 & 0.03 & 1.06 \\
CV (\%) & 8.87 & 10.2 & 5.90 & 11.0 & 8.51 & 7.10 \\
\hline
\end{tabular}

$\mathrm{N}_{0}=$ control (no nitrogen), $\mathrm{N}_{1}=84 \mathrm{~kg} \mathrm{~N} \mathrm{ha}^{-1}$ from USG, $\mathrm{N}_{2}=30 \mathrm{~kg} \mathrm{~N}^{-1}$ from prilled urea, $\mathrm{N}_{3}=50 \mathrm{~kg} \mathrm{~N} \mathrm{ha}{ }^{-1}$ from prilled urea and $\mathrm{N}_{4}=70 \mathrm{~kg} \mathrm{~N} \mathrm{ha}^{-1}$ from prilled urea

Table 4. Plant height of wheat varieties as influenced by interaction of variety and prilled urea or urea super granules (USG) at different dates from November 2011 to March 2012

\begin{tabular}{|c|c|c|c|c|c|c|c|}
\hline \multirow{2}{*}{$\begin{array}{l}\text { Interaction } \\
\text { (Variety x Nitrogen) }\end{array}$} & \multicolumn{7}{|c|}{ Plant height $(\mathrm{cm})$ at different days after sowing } \\
\hline & 15 & 30 & 45 & 60 & 75 & 90 & At harvest \\
\hline $\mathrm{V}_{1} \mathrm{~N}_{0}$ & 32.3 & 32.6 & 47.2 & 82.2 & 95.2 & 95.9 & 93.6 \\
\hline $\mathrm{V}_{1} \mathrm{~N}_{1}$ & 31.1 & 34.1 & 49.3 & 84.6 & 94.1 & 97.4 & 96.9 \\
\hline $\mathrm{V}_{1} \mathrm{~N}_{2}$ & 31.0 & 36.7 & 52.3 & 86.2 & 95.0 & 97.2 & 96.6 \\
\hline $\mathrm{V}_{1} \mathrm{~N}_{3}$ & 30.3 & 34.6 & 47.8 & 87.5 & 98.2 & 100.4 & 100.0 \\
\hline $\mathrm{V}_{1} \mathrm{~N}_{4}$ & 32.5 & 35.3 & 52.5 & 85.4 & 92.3 & 98.83 & 97.8 \\
\hline $\mathrm{V}_{2} \mathrm{~N}_{0}$ & 32.4 & 35.8 & 57.7 & 86.1 & 86.8 & 86.5 & 85.8 \\
\hline $\mathrm{V}_{2} \mathrm{~N}_{1}$ & 33.9 & 36.2 & 51.8 & 88.2 & 93.3 & 95.6 & 92.3 \\
\hline $\mathrm{V}_{2} \mathrm{~N}_{2}$ & 30.9 & 35.4 & 53.8 & 85.8 & 89.7 & 91.3 & 91.1 \\
\hline $\mathrm{V}_{2} \mathrm{~N}_{3}$ & 34.5 & 34.7 & 54.4 & 89.8 & 89.8 & 92.2 & 91.4 \\
\hline $\mathrm{V}_{2} \mathrm{~N}_{4}$ & 30.0 & 32.9 & 54.4 & 86.0 & 91.9 & 94.3 & 92.3 \\
\hline $\mathrm{V}_{3} \mathrm{~N}_{0}$ & 34.4 & 36.8 & 48.1 & 89.6 & 91.5 & 91.9 & 96.2 \\
\hline $\mathrm{V}_{3} \mathrm{~N}_{1}$ & 30.6 & 33.4 & 56.9 & 86.0 & 89.4 & 92.7 & 93.7 \\
\hline $\mathrm{V}_{3} \mathrm{~N}_{2}$ & 34.3 & 37.0 & 52.5 & 85.1 & 90.4 & 93.2 & 92.2 \\
\hline $\mathrm{V}_{3} \mathrm{~N}_{3}$ & 34.5 & 40.7 & 59.3 & 90.1 & 91.8 & 95.7 & 92.9 \\
\hline $\mathrm{V}_{3} \mathrm{~N}_{4}$ & 31.5 & 36.2 & 54.6 & 89.9 & 91.2 & 92.2 & 91.1 \\
\hline $\mathrm{V}_{4} \mathrm{~N}_{0}$ & 32.2 & 35.7 & 55.4 & 85.6 & 89.5 & 90.3 & 91.2 \\
\hline $\mathrm{V}_{4} \mathrm{~N}_{1}$ & 32.0 & 34.5 & 57.1 & 85.6 & 90.6 & 91.9 & 92.5 \\
\hline $\mathrm{V}_{4} \mathrm{~N}_{2}$ & 31.1 & 35.2 & 58.7 & 84.8 & 93.8 & 96.7 & 92.3 \\
\hline $\mathrm{V}_{4} \mathrm{~N}_{3}$ & 32.8 & 35.5 & 56.4 & 84.7 & 93.3 & 94.1 & 99.2 \\
\hline $\mathrm{V}_{4} \mathrm{~N}_{4}$ & 33.2 & 39.1 & 54.9 & 87.2 & 88.3 & 90.8 & 92.8 \\
\hline LSD (0.05) & 0.35 & 0.57 & 1.64 & 1.00 & 1.31 & 1.38 & 1.40 \\
\hline CV (\%) & 8.17 & 10.4 & 10.5 & 7.12 & 8.33 & 9.00 & 9.44 \\
\hline
\end{tabular}

$\mathrm{V}_{1}=$ BARI Gom 21, $\mathrm{V}_{2}=$ BARI Gom 24, $\mathrm{V}_{3}=$ BARI Gom 25 and $\mathrm{V}_{4}=$ BARI Gom 26; $\mathrm{N}_{0}=$ control (no nitrogen), $\mathrm{N}_{1}=84 \mathrm{~kg} \mathrm{~N}^{-1}$ from USG, $\mathrm{N}_{2}=30 \mathrm{~kg} \mathrm{~N}$ ha-1from prilled urea, $\mathrm{N}_{3}=50 \mathrm{~kg} \mathrm{~N}^{-1}$ from

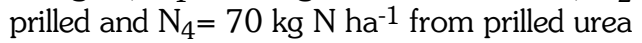


Performance of Prilled Urea and USG on the Growth and Yield of Wheat

Number of tillers plant ${ }^{-1}$ was significantly influenced by the interaction of variety and nitrogenous fertilizer at different DAS (Table 5). Results showed that the maximum number of tillers plant ${ }^{-1}$ was obtained from $\mathrm{V}_{2} \mathrm{~N}_{1}$ at $15,30,45,60,75,90$ DAS and at harvest $(3.5,4.0$, $4.4,4.8,5.4,5.8$ and 5.8 , respectively) which was statistically similar with $\mathrm{V}_{4} \mathrm{~N}_{2}$ and $\mathrm{V}_{4} \mathrm{~N}_{3}$ at 30 DAS and 75 DAS, respectively. On the other hand the minimum number of tillers plant ${ }^{-1}$ at $15,30,45,60,75,90$ DAS and at harvest was observed as 2.3, 2.6, 2.7, 3.4, 4.3, 3.5 and 3.3 , respectively, with $\mathrm{V}_{3} \mathrm{~N}_{0}$ which was statistically similar to $\mathrm{V}_{1} \mathrm{~N}_{0}$ at 15 and 60 DAS.

Table 5. Number of tillers plant ${ }^{-1}$ as influenced by interaction of variety and prilled urea or urea super granules (USG) during the period from November' 2011 to March' 2012

\begin{tabular}{|c|c|c|c|c|c|c|c|}
\hline \multirow{2}{*}{$\begin{array}{l}\text { Interaction } \\
\text { (Variety x Nitrogen) }\end{array}$} & \multicolumn{7}{|c|}{ Number of tillers plant ${ }^{-1}$ at different days after sowing } \\
\hline & 15 & 30 & 45 & 60 & 75 & 90 & At harvest \\
\hline $\mathrm{V}_{1} \mathrm{~N}_{0}$ & 2.3 & 2.9 & 3.2 & 3.6 & 4.8 & 4.1 & 3.6 \\
\hline $\mathrm{V}_{1} \mathrm{~N}_{1}$ & 3.1 & 3.7 & 3.4 & 3.9 & 4.7 & 4.9 & 4.9 \\
\hline $\mathrm{V}_{1} \mathrm{~N}_{2}$ & 2.9 & 3.4 & 3.0 & 4.3 & 4.8 & 4.1 & 3.8 \\
\hline $\mathrm{V}_{1} \mathrm{~N}_{3}$ & 2.5 & 3.4 & 3.3 & 3.9 & 4.7 & 4.5 & 4.6 \\
\hline $\mathrm{V}_{1} \mathrm{~N}_{4}$ & 3.0 & 3.7 & 3.9 & 4.6 & 4.6 & 4.8 & 4.8 \\
\hline $\mathrm{V}_{2} \mathrm{~N}_{0}$ & 2.4 & 2.9 & 3.1 & 4.1 & 4.9 & 3.9 & 3.4 \\
\hline $\mathrm{V}_{2} \mathrm{~N}_{1}$ & 3.5 & 4.0 & 4.4 & 4.8 & 5.4 & 5.8 & 5.8 \\
\hline $\mathrm{V}_{2} \mathrm{~N}_{2}$ & 2.6 & 3.3 & 3.7 & 4.4 & 5.2 & 4.9 & 4.8 \\
\hline $\mathrm{V}_{2} \mathrm{~N}_{3}$ & 2.8 & 2.8 & 3.1 & 3.8 & 5.1 & 4.8 & 4.7 \\
\hline $\mathrm{V}_{2} \mathrm{~N}_{4}$ & 2.3 & 2.7 & 3.6 & 4.4 & 5.1 & 5.2 & 5.1 \\
\hline $\mathrm{V}_{3} \mathrm{~N}_{0}$ & 2.3 & 2.6 & 2.7 & 3.4 & 4.3 & 3.4 & 3.3 \\
\hline $\mathrm{V}_{3} \mathrm{~N}_{1}$ & 2.7 & 3.7 & 3.2 & 4.1 & 4.7 & 4.7 & 5.0 \\
\hline $\mathrm{V}_{3} \mathrm{~N}_{2}$ & 3.1 & 2.9 & 4.0 & 4.4 & 4.9 & 4.5 & 4.5 \\
\hline $\mathrm{V}_{3} \mathrm{~N}_{3}$ & 3.1 & 3.5 & 3.2 & 4.2 & 4.9 & 4.3 & 4.2 \\
\hline $\mathrm{V}_{3} \mathrm{~N}_{4}$ & 2.9 & 3.1 & 3.1 & 3.9 & 4.8 & 4.6 & 4.6 \\
\hline $\mathrm{V}_{4} \mathrm{~N}_{0}$ & 2.6 & 3.2 & 2.9 & 4.2 & 4.7 & 3.5 & 3.4 \\
\hline $\mathrm{V}_{4} \mathrm{~N}_{1}$ & 2.8 & 3.2 & 2.8 & 4.2 & 4.7 & 5.1 & 5.3 \\
\hline $\mathrm{V}_{4} \mathrm{~N}_{2}$ & 3.3 & 4.0 & 3.8 & 4.3 & 5.2 & 4.8 & 4.7 \\
\hline $\mathrm{V}_{4} \mathrm{~N}_{3}$ & 2.3 & 3.3 & 3.2 & 4.3 & 5.4 & 4.9 & 4.0 \\
\hline $\mathrm{V}_{4} \mathrm{~N}_{4}$ & 2.5 & 3.1 & 2.8 & 4.5 & 4.9 & 4.67 & 4.5 \\
\hline $\mathrm{LSD}_{0.05}$ & 0.20 & 0.22 & 0.21 & 0.18 & 0.23 & 0.14 & 0.23 \\
\hline CV $(\%)$ & 10.1 & 15.2 & 16.1 & 13.2 & 11.1 & 10.4 & 10.2 \\
\hline
\end{tabular}

$\mathrm{V}_{1}=\mathrm{BARI}$ Gom 21, $\mathrm{V}_{2}=$ BARI Gom 24, $\mathrm{V}_{3}=$ BARI Gom 25 and $\mathrm{V}_{4}=\mathrm{BARI}$ Gom 26; $\mathrm{N}_{0}=$ control (no nitrogen), $N_{1}=80 \mathrm{~kg} \mathrm{~N}^{-1}$ from USG, $\mathrm{N}_{2}=80 \mathrm{~kg} \mathrm{~N}^{-1}$ from prilled urea, $\mathrm{N}_{3}=100 \mathrm{~kg} \mathrm{~N} \mathrm{ha}^{-1}$ from prilled urea and $\mathrm{N}_{4}=120 \mathrm{~kg} \mathrm{~N}^{-1}$ from prilled urea

Dry weight plant ${ }^{-1}$ was significantly influenced by interaction of variety and $\mathrm{N}$ at different DAS (Table 6). Results showed that the highest dry weight plant ${ }^{-1}$ was obtained from $\mathrm{V}_{2} \mathrm{~N}_{1}$ at 30 , 60, 90 DAS and at harvest $(0.64,7.73,18.8$ and $21.2 \mathrm{~g}$ respectively) which was statistically similar with $\mathrm{V}_{1} \mathrm{~N}_{1}, \mathrm{~V}_{3} \mathrm{~N}_{1}$ and $\mathrm{V}_{4} \mathrm{~N}_{1}$ at 30 DAS, but at 60,90 DAS and at harvest. On the other hand the lowest dry weight plant ${ }^{-1}$ at 30, 60, 90 DAS and at harvest was observed as 0.20 , $3.88,8.83$ and $10.36 \mathrm{~g}$ respectively with $\mathrm{V}_{3} \mathrm{~N}_{0}$.

The highest number of spikelets spike $e^{-1}$ was found the treatment combination of $\mathrm{V}_{2} \mathrm{~N}_{1}$ and the lowest number of spikelets spike 9.27 in $\mathrm{V}_{1} \mathrm{~N}_{0}$. Number of grains spike ${ }^{-1}$ was significantly influenced by interaction of variety and $\mathrm{N}$, where the highest number of grains spike ${ }^{-1}(46.3)$ was found the treatment combination of $\mathrm{V}_{2} \mathrm{~N}_{1}$. On the other hand, the lowest number of grains spike ${ }^{-1}$ (22.90) was observed in $\mathrm{V}_{1} \mathrm{~N}_{0}$. 
Nahal et al.

Table 6. Dry weight plant ${ }^{-1}$ as influenced by interaction of variety and prilled urea or urea super granules (USG) from November' 2011 to March' 2012

\begin{tabular}{l|ccccc}
\hline \multirow{2}{*}{$\begin{array}{c}\text { Interaction (Variety } x \\
\text { Nitrogen) }\end{array}$} & \multicolumn{4}{|c}{ Dry weight plant ${ }^{-1}(\mathrm{~g})$ at different days after sowing } \\
\cline { 2 - 5 } & 30 & 60 & 90 & At harvest \\
\hline $\mathrm{V}_{1} \mathrm{~N}_{0}$ & 0.20 & 4.1 & 9.8 & 11.2 \\
$\mathrm{~V}_{1} \mathrm{~N}_{1}$ & 0.63 & 7.3 & 17.0 & 20.2 \\
$\mathrm{~V}_{1} \mathrm{~N}_{2}$ & 0.55 & 6.5 & 15.6 & 16.7 \\
$\mathrm{~V}_{1} \mathrm{~N}_{3}$ & 0.45 & 6.4 & 16.7 & 19.4 \\
$\mathrm{~V}_{1} \mathrm{~N}_{4}$ & 0.53 & 6.2 & 17.3 & 18.2 \\
$\mathrm{~V}_{2} \mathrm{~N}_{0}$ & 0.23 & 4.4 & 9.9 & 10.7 \\
$\mathrm{~V}_{2} \mathrm{~N}_{1}$ & 0.64 & 7.7 & 18.8 & 21.2 \\
$\mathrm{~V}_{2} \mathrm{~N}_{2}$ & 0.42 & 6.4 & 16.6 & 18.4 \\
$\mathrm{~V}_{2} \mathrm{~N}_{3}$ & 0.46 & 6.9 & 17.3 & 19.9 \\
$\mathrm{~V}_{2} \mathrm{~N}_{4}$ & 0.47 & 6.8 & 15.9 & 20.7 \\
$\mathrm{~V}_{3} \mathrm{~N}_{0}$ & 0.20 & 3.8 & 8.8 & 10.4 \\
$\mathrm{~V}_{3} \mathrm{~N}_{1}$ & 0.61 & 7.3 & 17.0 & 19.3 \\
$\mathrm{~V}_{3} \mathrm{~N}_{2}$ & 0.46 & 6.2 & 13.8 & 16.6 \\
$\mathrm{~V}_{3} \mathrm{~N}_{3}$ & 0.48 & 6.2 & 14.2 & 17.6 \\
$\mathrm{~V}_{3} \mathrm{~N}_{4}$ & 0.52 & 6.1 & 14.3 & 19.7 \\
$\mathrm{~V}_{4} \mathrm{~N}_{0}$ & 0.22 & 4.1 & 9.9 & 10.9 \\
$\mathrm{~V}_{4} \mathrm{~N}_{1}$ & 0.61 & 7.2 & 17.7 & 20.7 \\
$\mathrm{~V}_{4} \mathrm{~N}_{2}$ & 0.47 & 5.6 & 16.1 & 18.0 \\
$\mathrm{~V}_{4} \mathrm{~N}_{3}$ & 0.46 & 5.7 & 14.2 & 17.9 \\
$\mathrm{~V}_{4} \mathrm{~N}_{4}$ & 0.53 & 6.4 & 15.9 & 17.3 \\
$\mathrm{LSD}_{0.05}$ & 0.07 & 0.3 & 0.5 & 0.35 \\
$\mathrm{CV}_{(\%)}$ & 10.3 & 12.8 & 9.7 & 10.3 \\
\hline
\end{tabular}

$\mathrm{V}_{1}=$ BARI Gom 21, $\mathrm{V}_{2}=$ BARI Gom 24, $\mathrm{V}_{3}=$ BARI Gom 25 and $\mathrm{V}_{4}=$ BARI Gom 26; $\mathrm{N}_{0}=$ control (no nitrogen), $\mathrm{N}_{1}=84 \mathrm{~kg} \mathrm{~N}$ ha-1 $^{-1}$ from USG, $\mathrm{N}_{2}=80 \mathrm{~kg} \mathrm{~N}$ ha-1 $^{-1}$ from prilled urea, $\mathrm{N}_{3}=100 \mathrm{~kg} \mathrm{~N} \mathrm{ha}^{-1}$ from prilled urea and $\mathrm{N}_{4}=120 \mathrm{~kg} \mathrm{~N}$ ha-1 $^{-1}$ from prilled urea

Weight of 1000 -grains was significantly influenced by interaction of variety and $\mathrm{N}$ (Table 7). The highest 1000-grain weight $(64.85 \mathrm{~g})$ was found in the treatment combination of $\mathrm{V}_{3} \mathrm{~N}_{1}$ which was statistically similar to $V_{1} N_{1}, V_{2} N_{1}$ and $V_{4} N_{1}$. On the other hand, the lowest 1000grain weight $(38.13 \mathrm{~g})$ was observed in $\mathrm{V}_{1} \mathrm{~N}_{0}$. Grain yield was significantly influenced by interaction of variety and $\mathrm{N}$ (Table 7). Results showed that the maximum grain yield (2.80 tha 1) was found in the treatment combination $V_{2} N_{1}$ which was statistically similar to $V_{4} N_{1}$ and $\mathrm{V}_{2} \mathrm{~N}_{4}$ while lower grain yield $\left(1.97 t \mathrm{tha}^{-1}\right)$ was observed with $\mathrm{V}_{3} \mathrm{~N}_{0}$ and $\mathrm{V}_{4} \mathrm{~N}_{0}$ which was statistically similar to $V_{1} N_{0}$ and $V_{2} N_{0}$. The maximum straw yield $\left(3.67 t\right.$ ha $\left.{ }^{-1}\right)$ was found in $\mathrm{V}_{2} \mathrm{~N}_{3}$ which was statistically similar to $\mathrm{V}_{3} \mathrm{~N}_{4}$ and $\mathrm{V}_{4} \mathrm{~N}_{1}$. On the other hand the lowest straw yield (3.36 tha-1) was observed in $V_{2} N_{0}$ which was statistically similar to $V_{2} N_{0}$ and $V_{4} N_{0}$ The maximum harvest index (45.39\%) was found with the treatment combination $V_{2} \mathrm{~N}_{1}$ which was statistically similar to $\mathrm{V}_{4} \mathrm{~N}_{1}$ while lowest harvest index (34.98\%) was observed in $\mathrm{V}_{3} \mathrm{~N}_{0}$ which was statistically similar to $\mathrm{V}_{4} \mathrm{~N}_{0}$. 
Performance of Prilled Urea and USG on the Growth and Yield of Wheat

Table 7. Yield and yield contributing parameters and harvest index of wheat as influenced by variety and prilled urea or urea super granules (USG)

\begin{tabular}{|c|c|c|c|c|c|c|}
\hline $\begin{array}{l}\text { Interaction } \\
\text { (Variety x } \\
\text { Nitrogen) }\end{array}$ & $\begin{array}{c}\text { Number of } \\
\text { spikelets } \\
\text { spike }^{-1}\end{array}$ & $\begin{array}{l}\text { Number of } \\
\text { grains spike }{ }^{-1}\end{array}$ & $\begin{array}{c}\text { 1000-grain } \\
\text { weight } \\
\text { (g) }\end{array}$ & $\begin{array}{c}\text { Grain yield } \\
\left(\mathrm{t} \mathrm{ha}^{-1}\right)\end{array}$ & $\begin{array}{c}\text { Straw yield } \\
\left(\mathrm{t} \mathrm{ha} \mathrm{h}^{-1}\right)\end{array}$ & $\begin{array}{l}\text { Harvest } \\
\text { index (\%) }\end{array}$ \\
\hline $\mathrm{V}_{1} \mathrm{~N}_{0}$ & 9.2 & 22.90 & 38.13 & 2.03 & 3.52 & 36.32 \\
\hline $\mathrm{V}_{1} \mathrm{~N}_{1}$ & 20.1 & 43.68 & 64.75 & 2.53 & 3.55 & 41.88 \\
\hline $\mathrm{V}_{1} \mathrm{~N}_{2}$ & 18.2 & 38.33 & 53.83 & 2.47 & 3.60 & 40.64 \\
\hline $\mathrm{V}_{1} \mathrm{~N}_{3}$ & 17.7 & 37.68 & 54.62 & 2.12 & 3.57 & 37.22 \\
\hline $\mathrm{V}_{1} \mathrm{~N}_{4}$ & 18.0 & 38.18 & 52.07 & 2.45 & 3.61 & 40.42 \\
\hline $\mathrm{V}_{2} \mathrm{~N}_{0}$ & 9.4 & 23.87 & 48.95 & 2.02 & 3.36 & 36.16 \\
\hline $\mathrm{V}_{2} \mathrm{~N}_{1}$ & 22.3 & 46.34 & 64.38 & 2.80 & 3.56 & 45.39 \\
\hline $\mathrm{V}_{2} \mathrm{~N}_{2}$ & 17.9 & 36.51 & 56.11 & 2.30 & 3.61 & 38.94 \\
\hline $\mathrm{V}_{2} \mathrm{~N}_{3}$ & 18.0 & 37.94 & 59.59 & 2.37 & 3.67 & 39.18 \\
\hline $\mathrm{V}_{2} \mathrm{~N}_{4}$ & 18.4 & 40.66 & 61.51 & 2.70 & 3.42 & 44.13 \\
\hline $\mathrm{V}_{3} \mathrm{~N}_{0}$ & 9.3 & 24.44 & 50.87 & 1.97 & 3.42 & 34.98 \\
\hline $\mathrm{V}_{3} \mathrm{~N}_{1}$ & 19.0 & 41.14 & 64.85 & 2.63 & 3.61 & 43.51 \\
\hline $\mathrm{V}_{3} \mathrm{~N}_{2}$ & 16.7 & 33.42 & 59.04 & 2.23 & 3.54 & 38.68 \\
\hline $\mathrm{V}_{3} \mathrm{~N}_{3}$ & 16.9 & 34.32 & 57.64 & 2.17 & 3.53 & 38.05 \\
\hline $\mathrm{V}_{3} \mathrm{~N}_{4}$ & 16.7 & 34.01 & 60.89 & 2.38 & 3.66 & 39.45 \\
\hline $\mathrm{V}_{4} \mathrm{~N}_{0}$ & 9.8 & 28.24 & 43.08 & 1.97 & 3.39 & 35.32 \\
\hline $\mathrm{V}_{4} \mathrm{~N}_{1}$ & 21.1 & 45.04 & 64.66 & 2.78 & 3.65 & 45.07 \\
\hline $\mathrm{V}_{4} \mathrm{~N}_{2}$ & 18.2 & 37.86 & 58.15 & 2.63 & 3.56 & 42.53 \\
\hline $\mathrm{V}_{4} \mathrm{~N}_{3}$ & 17.4 & 36.18 & 59.61 & 2.62 & 3.53 & 42.35 \\
\hline $\mathrm{V}_{4} \mathrm{~N}_{4}$ & 16.5 & 34.14 & 56.06 & 2.42 & 3.61 & 40.13 \\
\hline $\mathrm{LSD}_{0.05}$ & 0.49 & 1.040 & 1.80 & 0.104 & 0.05 & 0.72 \\
\hline CV (\%) & 8.8 & 10.16 & 5.90 & 11.09 & 8.51 & 7.10 \\
\hline
\end{tabular}

$\mathrm{V}_{1}=$ BARI Gom 21, $\mathrm{V}_{2}=$ BARI Gom 24, $\mathrm{V}_{3}=$ BARI Gom 25 and $\mathrm{V}_{4}=$ BARI Gom 26; $\mathrm{N}_{0}=$ control (no nitrogen), $N_{1}=84 \mathrm{~kg} \mathrm{~N}^{-1}$ from USG, $\mathrm{N}_{2}=80 \mathrm{~kg} \mathrm{~N}^{-1}$ from prilled urea, $\mathrm{N}_{3}=100 \mathrm{~kg} \mathrm{~N}^{-1}$ from prilled urea and $\mathrm{N}_{4}=120 \mathrm{~kg} \mathrm{~N}^{-1}$ from prilled urea

\section{Conclusion}

The results of the experiment revealed that the variety BARI Gom 24 gave the maximum grain yield that was similar to the variety BARI Gom 26 . So, both the varieties may be recommended for wheat cultivation for obtaining the maximum yield. Among the different nitrogenous fertilizer, the highest grain yield was obtained from $84 \mathrm{~kg} \mathrm{~N} \mathrm{ha}^{-1}$ from urea super granules (USG). Among the interaction effect the combination of $84 \mathrm{~kg} \mathrm{~N}^{-1} \mathrm{a}^{-1}$ from USG along with the variety BARI Gom 24 performed best in case of grain yield that was statistically similar to the variety BARI Gom 26. Therefore, wheat variety BARI Gom 24 and BARI Gom 26 could perform better with $84 \mathrm{~kg} \mathrm{~N}^{-1}{ }^{-1}$ from USG.

\section{References}

Akter, H. 2005. Yield and seed quality of wheat cultivars as influenced by fertilizer nitrogen level under rainfed and irrigated conditions. M. Sc. Thesis, Dept. of Agronomy, Bangladesh Agril. Univ., Mymensingh.

BBS (Bangladesh Bureau of Statistics). 2008. Statistical Year Book of Bangladesh. Statistics division, Ministry of planning. Government of the peoples of Bangladesh. 
Nahal et al.

Donald, C.M. 1963. Competition among crop and pasture plants. Adv. Agron.15:1-118.

FRG (Fertilizer Recommendation Guide). 2005, Bangladesh Agricultural Research Council, Farmgate, Dhaka-1215.

Hossain, K. I., C. A. Meisner, J, M. Duxbury, J. G. Lauren, M. M. Rahman, M. M. Meer and M. H. Rashid. 2005. Use of raised beds for increasing wheat production in rice-wheat cropping systems. Bed planting course, CIMMYT. Mexico. Indian J. Agron. 40(4): 51-511.

Khalil, M. I., U. Schmidhalter, R. Gutser, and H. Heuwinkel. 2011. Comparative efficacy of urea fertilization via supergranules versus prills on nitrogen distribution, yield response and nitrogen use efficiency of spring wheat. J. Plant Nutr. 34(6):779-797.

Mozumder, A. S. M. M. H. 2001. Effect of different seed rates and levels of nitrogen on the performance of Shourav variety of wheat M. Sc. Thesis, Dept. of Agronomy, Banagladesh Agril. Univ., Mymensingh.

Nadim, M. A., I. U. Awan, M. S. Baloch, E. A. Khan, K. Naveed and M. A. Khan. 2012. Response of wheat (Triticum aestivum L.) to different micronutrients and their application methods. J. Animal Plant Sci. 22(1):113-119.

Onsongo, M. 2003. Kenya Grain and Feed Wheat Uptake. USDA Global Agriculture Information Network. GAINREPORT \# KE3011.

Rahman, A.M. 2009. Growth and yield components of wheat genotypes exposed to high temperature stress under control environment. Bangladesh J. Agril. Res. 34: 361-372.

Rahman, M. I. 2005. Yield and quality of wheat as influenced by nitrogen sulphr and boron under irrigated and rainfed conditions. M. Sc. Thesis, Dept. of Agronomy. Bangladesh Agril. Univ., Mymensingh.

Rahman, M.M., A. Hossain, M.A. Hakim, M.R. Kabir and M.M.R. Shah. 2009. Performance of wheat genotypes under optimum and late sowing condition. Int. J. Sustain. Crop Prod. 4(6): 34-39.

Saari, F. 1998. Leaf blight diseases and associated soil born fungal pathogens of wheat in south and south East Asia. CIMMYT. pp. 37-51.

Sarker, M. A. Z., M. G. Miah, A. Hamid, J. Haider and A. Hashem. 1997. Effect of nitrogen level and duration of weed competition on weed biomass, yield and yield attributes of wheat. Ann. Bangladesh Agric. 7(1): 1-7.

Sikder, S. J. U. Ahmed and T. Hossain. 2001. Heat tolerance and relative yield performance of wheat varieties under late seeded conditions. Bangladesh. Indian J. Agric. Res. 35(3): 141-148.

Singh, G. R. Singh and K. Purashhttam. 1986. Response of wheat (Triticum aestivum) to nitrogen, phosphorus and potassium fertilization, Indian J. Agron. 41(1): 157-159.

Tariq, M. T. 2010. Evaluation of two wheat genotypes performance under drought conditions at different growth stages. Department of Agronomy, University of Agriculture, Faisalabad, Pakistan.

Yadav, D. S., R. P. Shukla, Sushant and B. Kumer. 2005. Effect of zero tillage and nitrogen level on wheat (Triticum aestivum) after rice (Oryza sativa). Indian J. Agron. 50(1): 52-53. 